\title{
Brazilian agroforestry systems for cattle and sheep
}

\author{
ROBERTO G. DE ALMEIDA ${ }^{1}$, CARLOS MAURÍCIO S. DE ANDRADE ${ }^{2}$, DOMINGOS S.C. PACIULLO ${ }^{3}$, PAULO \\ C.C. FERNANDES ${ }^{4}$, ANA CLARA R. CAVALCANTE ${ }^{5}$, RODRIGO A. BARBOSA ${ }^{1}$ AND CACILDA B. DO VALLE $^{1}$ \\ ${ }^{1}$ Empresa Brasileira de Pesquisa Agropecuária, Embrapa Gado de Corte, Campo Grande, MS, Brazil. \\ www.cnpgc.embrapa.br \\ ${ }^{2}$ Empresa Brasileira de Pesquisa Agropecuária, Embrapa Acre, Rio Branco, AC, Brazil. www.cpafac.embrapa.br \\ ${ }^{3}$ Empresa Brasileira de Pesquisa Agropecuária, Embrapa Gado de Leite, Juiz de Fora, MG, Brazil. \\ www.cnpgl.embrapa.br \\ ${ }^{4}$ Empresa Brasileira de Pesquisa Agropecuária, Embrapa Amazônia Oriental, Belém, PA, Brazil. www.cpatu.embrapa.br \\ ${ }^{5}$ Empresa Brasileira de Pesquisa Agropecuária, Embrapa Caprinos e Ovinos, Sobral, CE, Brazil.www.cnpc.embrapa.br
}

Keywords: Beef cattle, Brazilian regions, integrated crop-livestock-forest systems, tropical grasslands.

\begin{abstract}
Agroforestry systems for animal husbandry in Brazil, including integrated crop-livestock-forest systems (ICLF), are very diverse, and present several technical, environmental and socio-economic benefits. For each of the country's 5 regions (Southeast, Central-West, North, Northeast and South) the prevailing agroforestry systems holding animals are presented, their potential and constraints discussed and research needs identified. In general, such systems are not broadly adopted, mainly because of their level of complexity compared with traditional systems, as well as some lack of understanding by farmers regarding their benefits. To change this situation, in the last 5 years, the Brazilian Government has allocated financial resources in terms of credit for development as well as for research and technology transfer addressing ICLF systems, including good agricultural practices and mitigation of greenhouse gas emissions. The goal is to improve competitiveness of the Brazilian agribusiness sector.
\end{abstract}

\section{Resumen}

Los sistemas agroforestales para producción animal, que incluyen sistemas integrados de cultivos, ganadería y árboles (ICLF, por su sigla en inglés), son bastante diversos en Brasil. Estos sistemas presentan varios beneficios técnicos, ambientales y económicos. Para cada una de las 5 regiones del país (Sureste, Centro-Oeste, Norte, Nordeste y Sur) se presentan los sistemas prevalentes de agroforestería con animales, se discuten su potencial y limitaciones y se identifican tópicos de investigación. En general, estos sistemas no han sido ampliamente adoptados por los productores, debido principalmente a su alta complejidad que dificulta su implementación comparados con los sistemas tradicionales, pero también por cierta falta de reconocimiento de sus beneficios por parte de los productores. Para cambiar esta situación, durante los últimos 5 años el gobierno de Brasil ha destinado recursos financieros para créditos, investigación y transferencia de tecnología hacia los sistemas ICFL, incluyendo buenas prácticas agrícolas y la reducción de emisión de gases con efecto invernadero para, de esta forma, mejorar la competitividad de la agricultura del país.

\section{Introduction}

Agroforestry systems are being used in all Brazilian regions (Southeast, Central-West, North, Northeast and South), with combination of several plant and animal

Correspondence: Roberto Giolo de Almeida, Embrapa Gado de Corte, Avenida Rádio Maia, 830 - Zona Rural, Campo Grande CEP 79106550, MS, Brazil.

Email: roberto.giolo@embrapa.br species, using many arrangements of components in time and space. They can have many purposes and functionalities in only one system, usually focused on subsistence agriculture. In turn, the Brazilian ICLF systems (ILPF in Portuguese), have the tendency to be commercial operations. They usually encompass two or three components handled as mechanized plantations with rotation of crops and pastures using no-till systems (Macedo 2010; Balbino et al. 2011a). These systems allow high land use efficiency, with resulting technical, environmental and socioeconomic benefits. 
Information about traditional cattle systems, integrated crop-livestock systems (without the tree component) and the evolution of studies with forage species and pastures in Brazil can be found in Ferraz and Felício (2010), Carvalho et al. (2010) and Euclides et al. (2010), respectively.

According to Costa et al. (2011), despite favorable environmental conditions and land availability in Brazil, sheep husbandry is not well developed in terms of total production or yields of meat and hides, when compared with countries like Uruguay, Argentina, New Zealand and Australia. About 54\% of the flock in Brazil are hair sheep breeds, concentrated in the semi-arid environment of the Northeast (Table 1). The remainder are spread in the other regions, especially Rio Grande do Sul (southern Brazil) with $23 \%$ of the national flock. With a cattle herd of 212.8 M head (IBGE 2011), Brazil is one of the largest beef exporters in the world. Cattle ranching is spread throughout the country, being a very important economic activity. However, statistics for herd rearing in agroforestry systems are limited.

Official data indicate that only $10.7 \%$ of sown pasture areas are degraded, even though some authors indicate, in recent decades, that more than half of the sown pastures in Brazil are degraded to some degree, either in the Cerrado biome (Sano et al. 1999; Zimmer and Euclides 2000) or Rain Forest biome (Serrão et al. 1993).

According to Balbino et al. (2011b), Brazil has around 67.8 Mha of land suitable for different ICLF models, with no need for further clearing of areas of original vegetation. In 2010, it was estimated that a total area of 1.6 Mha was covered with specific ICLF systems, while the official census from 2006 indicated an area of 4.12 Mha with agroforestry systems holding cattle (Table 1).

In the context of livestock husbandry, ICLF systems display micro-climate improvement for grazing animals and have been adopted as alternatives for sown pasture reclamation, farm diversification and intensification.
According to Zimmer et al. (2012), average beef yields on natural grasslands and sown, i.e. "improved" pastures under traditional management, are, respectively, 30 and 90 $\mathrm{kg} / \mathrm{ha} / \mathrm{yr}$, while potential yields for improved pastures, either using traditional reclamation or adopting ICLF systems, are, respectively, 180 and $340 \mathrm{~kg} / \mathrm{ha} / \mathrm{yr}$. This illustrates the substantial progress the Brazilian cattle industry can achieve in the next few years if ICLF systems are adopted to satisfy domestic and export demand for beef.

From an environmental perspective, ICLF systems with 250-350 eucalypt (Eucalyptus spp.) trees per hectare, designed for harvesting trees between 8 and 12 years, would yield $25 \mathrm{~m}^{3}$ wood/ha/yr (Ofugi et al. 2008).This corresponds to an annual sequestration of around $5 \mathrm{t} / \mathrm{ha}$ carbon or $18 \mathrm{t} / \mathrm{ha} \mathrm{CO}_{2}$-eq, which would compensate for $\mathrm{GHG}$ emissions of 12 adult beef animals. However, due to the higher complexity of ICLF systems, their adoption remains limited, though growing in the last 5 years.

Availability of official credit for implementing ICLF systems from 2008, through the 'Programa de Produção Sustentável do Agronegócio (Produsa)' (Sustainable Agribusiness Program), has attracted farmers to adopt these technologies. In 2009, from the commitment made at the COP-15, Copenhagen, the Brazilian Government created a program named ABC, 'Agricultura de Baixa Emissão de Carbono' (Low Carbon Emissions Agriculture), with the goal of stimulating voluntary reduction of GHG emissions from the agricultural sector. This program makes available credit for reclaiming 15 Mha of degraded pastures, including implementation of ICLF systems on 4 Mha by 2020 . Demand for professionals specialized in design and implementation of ICLF projects exceeds their availability and is a critical limit to development of such systems (Almeida et al. 2012b). The Brazilian Agricultural Research Corporation (Embrapa), together with some state research organizations, universities and private companies, has

Table 1. Cattle and sheep herds (data from 2011), areas of natural grasslands, sown pastures in good condition and degraded, and areas with agroforestry systems (AFS) holding cattle (data from 2006) per region.

\begin{tabular}{|c|c|c|c|c|c|c|}
\hline \multirow[t]{2}{*}{ Region } & \multirow[t]{2}{*}{ Cattle $^{1}$} & \multirow[t]{2}{*}{ Sheep $^{1}$} & \multirow{2}{*}{$\begin{array}{c}\text { Natural } \\
\text { grasslands }\end{array}$} & \multicolumn{2}{|c|}{ Sown pastures $^{2}$} & \multirow[t]{2}{*}{$\mathrm{AFS}^{3}$} \\
\hline & & & & $\begin{array}{c}\text { Good } \\
\text { condition }\end{array}$ & Degraded & \\
\hline & \multicolumn{2}{|c|}{--------- M head (\%) ---------- } & ------------------. & --- M ha & \%) --------- & 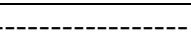 \\
\hline Southeast & $39.34(19)$ & $0.77(4)$ & $10.96(19)$ & $15.21(17)$ & $1.66(17)$ & $0.58(14)$ \\
\hline Central-West & $72.66(34)$ & $1.21(7)$ & $13.81(24)$ & $41.87(45)$ & $3.36(34)$ & $0.56(14)$ \\
\hline North & $43.24(20)$ & $0.63(4)$ & $6.00(10)$ & $18.70(20)$ & $2.20(22)$ & $0.61(15)$ \\
\hline Northeast & $29.59(14)$ & $10.11(57)$ & $16.03(28)$ & $12.34(13)$ & $2.24(23)$ & $2.15(52)$ \\
\hline South & $27.99(13)$ & $4.95(28)$ & $10.84(19)$ & $4.39(5)$ & $0.45(4)$ & $0.22(5)$ \\
\hline Brazil & 212.82 & 17.67 & 57.64 & 92.51 & 9.91 & 4.12 \\
\hline
\end{tabular}

Source: IBGE 2011; ${ }^{1}$ source: IBGE 2006a; ${ }^{3}$ source: IBGE $2006 \mathrm{~b}$. 
focused on demonstrating the benefits of these systems in an endeavor to expand their promotion, through establishing Technology Reference Units (TRUs) in several strategic locations throughout Brazil. These demonstration fields are usually located on private farms, in a partnership arrangement. While serving as a demonstration, these TRUs are also used for technical and scientific observations for improving the systems, based on observations by farmers and scientists involved (Porfírio-da-Silva and Baggio 2003). In 2011 there were 194 TRUs in operation throughout Brazil (Balbino et al. 2011b; Almeida et al. 2012b). More recently, Embrapa and its national and international partners created the Pecus Network (www. cppse. embrapa.br/redepecus/) with the aim of studying integrated cattle production systems, comparing improved management techniques with traditional systems, reducing GHG emissions and increasing carbon sequestration in order to provide guidelines for official policies regarding the sector in Brazil.

The next sections will discuss integrated systems for animal husbandry in the 5 Brazilian regions, based on an array of economic, social and political peculiarities and their interactions with local conditions.

\section{Southeast Region}

The Southeast region encompasses the States of Espírito Santo, Minas Gerais, Rio de Janeiro and São Paulo, covering an area of $0.92 \mathrm{Mkm}^{2}$, representing $11 \%$ of the Brazilian territory. It is the most industrialized and richest part of Brazil. Its climate is predominantly tropical, with some areas having high-elevation tropical climate, subtropical and humid-coastal. The region usually has 2 welldefined seasons, one hot and rainy (Spring-Summer) and the other with little rain and lower temperatures (Fall-Winter). Tropical forest (Atlantic Forest) was the original dominant vegetation, which, as a result of deforestation, now occupies less than $10 \%$ of the original area.

The Southeast region has 27.8 Mha of pastures, supporting $39.3 \mathrm{M}$ cattle and $0.7 \mathrm{M}$ sheep (IBGE 2006a; 2011), and has a well-developed and diversified agribusiness sector. Cattle production, especially dairy, is important in the region. It was originally based on Melinis minutiflora and Hyparrhenia rufa pastures, which were later replaced by Brachiaria and Panicum grasses, which dominate the grazing systems in the area. The first integrated systems in the region were non-systematic, mainly through cattle grazing in eucalypt plantations held by commercial afforestation companies at the end of the 1970 s and early 1980s (Garcia and Couto 1997). In such systems, cattle grazing reduced implementation costs and helped to control understory vegetation, reducing fire risk in the es- tablishment years. From the 1990s onwards, research on actual silvopastoral systems, in which tree and cattle components were intended to co-exist in the system during its whole productive cycle, was intensified. In both systems, the main tree species used were from the genera Eucalyptus and the closely related Corymbia, while Brachiaria was used for pastures. At that time, a pasture shading model was started, using leguminous tree species to reduce inloco temperatures and therefore to reduce heat stress on animals. This would also contribute nutrients to the system, especially nitrogen, through biological fixation of atmospheric $\mathrm{N}$ by these species. In the long term, improving soil fertility would improve yields and the better pasture would reduce soil exposure, promoting pasture sustainability (Carvalho et al. 2001).

Systematically including a crop component in the model, characteristic of ICLF systems, happened only in the late 1990s, mainly using maize, sorghum, rice or soybean integrated with Eucalyptus spp. and Brachiaria spp. Adoption of integrated systems had been limited by scarce resources for implementation as well as by the small number of qualified professionals for technical advice. The high initial investment problem has been solved by availability of financial resources through federal and state credit policies for the sector. In parallel, regular training opportunities for agriculture-related professionals, through continued education and courses, have improved the availability of technical advice in the area. Such initiatives are starting to show results, as demonstrated through the increasing numbers of integrated systems implemented in different parts of the Southeast region. The model, using eucalypt tree plantations, cultivated in rows 10-20 m apart over Brachiaria spp. pastures, with or without integrating annual crops, has expanded over traditional grazing areas. For beef production, the cattle breed is usually Nelore, whereas for dairy, a crossbred Holstein $x$ Zebu cow is mostly used.

With integrated systems, competition for light, nutrients and water increases as trees grow. Degree of shading on understory species progressively increases, causing morphological and physiological changes in the forage. Intense shading, usually eliminating more than $50 \%$ of photosynthetically active radiation, drastically reduces forage yields from pastures, endangering their persistence and therefore the sustainability of the system (Paciullo et al. 2010). For this reason, management strategies for the tree component must allow only moderate reduction of radiation incidence on pastures. When using Eucalyptus spp., the most convenient distances between tree rows result in densities from 150 to 450 trees per hectare. One must also consider aspects like: tree component purpose (timber, fodder, shade/shelter); local relief characteristics, 
especially slope; machinery specifications when cultivating crops integrated with pasture; and finally on-farm management (paddock sizes, erosion control).

If the main goal is to produce higher quality timber (added value), a lower tree density is recommended (150-300 trees/ha) in single rows. On the other hand, higher densities using partial thinnings (4-5 years, 8-9 years and $12-15$ years) to allow higher radiation into the understory allows for financial income every 4 years. Regarding animal production, results have been satisfactory. Managed pastures in silvopastoral systems, with little or no fertilization, have shown carrying capacities from 1.5 to $2.5 \mathrm{AU} / \mathrm{ha}$, weight gains of $0.5-0.7 \mathrm{~kg} / \mathrm{animal} / \mathrm{d}$ and beef production of $200-350 \mathrm{~kg} / \mathrm{ha} / \mathrm{yr}$ (Bernardino et al. 2011; Paciullo et al. 2011). Some studies have shown that efficient fertilization can be carried out with moderate doses under moderate shading (Andrade et al. 2001; Bernardino et al. 2011). However, despite the growing adoption, the total area under these systems is still modest, when compared with the potential they have to improve agribusiness in the Southeast region.

\section{Central-West Region}

The Central-West region, or Central Brazil, is composed of the States of Goiás, Mato Grosso, Mato Grosso do Sul and the Federal District. The total area is $1.61 \mathrm{Mkm}^{2}$, representing $19 \%$ of the Brazilian territory, with an economy based essentially on agricultural activities. Having mostly a tropical climate with some subtropical areas in the southern part of the region, it has the largest cattle herd in Brazil with $72.6 \mathrm{M}$ head and $1.2 \mathrm{M}$ sheep, on a grazing area of 59 Mha (IBGE 2006a; 2011). The common cattle husbandry systems are dual-purpose and beef, with a predominance of Zebu cattle, especially the Nelore breed. Goiás State shows the most developed dairy systems of all states in the region.

The region has 3 major biomes: Pantanal, Rain Forest and Cerrado (savanna). The Pantanal biome is a floodable plain covering about $15 \%$ of the region. Its cattle systems are traditionally extensive cow-calf operations on natural grasslands, resulting in low production coefficients. In some non-flooded areas, Brachiaria spp. are sown for pasture.

In the Rain Forest biome in Central Brazil, the development of agroforestry systems for cattle is similar to those in Northern Brazil. Main forage used are Brachiaria species (B. brizantha, B. decumbens and B. humidicola) and, to some extent also Panicum maximum (cvv. Tanzânia, Mombaça and Massai). Grass-legume mixed pastures contain mostly Pueraria phaseoloides as the legume species (Teixeira et al. 2000).
The Cerrado biome, with a savanna type vegetation, covers over $50 \%$ of the region. Cattle systems are more variable. Integrated systems are predominantly associated with no-till crop systems mostly growing soybean, maize, sorghum and rice. The most used trees in these systems are from the genera Eucalyptus and Corymbia. According to Macedo (2005), the predominant forage species, ranked by area, are: Brachiaria decumbens $(55 \%)$, B. brizantha (20\%), Panicum maximum (12\%), B. humidicola (9\%) and others (4\%). In transition areas between Cerrado and Rain Forest, silvopastoral systems usually have a greater variety of trees, using either native (Schizolobium amazonicum, Swietenia macrophylla, Astronium fraxinifolium and Hevea brasiliensis) or introduced (Tectona grandis, Ochroma pyramidale, Khaya ivorensis, Acacia mangium and Azadirachta indica) species.

Under ICLF systems, crops are grown between tree rows for the first 2 or 3 years, so that trees can grow strong enough to tolerate animal browsing. Crops are then replaced by pastures until tree harvesting. Pasture production decreases with increased shading caused by trees; however, with densities from 227 to 357 trees per hectare, stocking rates range from 1.3 to $1.8 \mathrm{AU} / \mathrm{ha}$, weight gains from 0.4 to $0.7 \mathrm{~kg} / \mathrm{animal} / \mathrm{d}$ and beef production from 130 to $245 \mathrm{~kg} / \mathrm{ha} / \mathrm{yr}$ (Almeida et al. 2012a; 2012b).

Silvopastoral systems are usually used in areas with limitations for grain crops, like poor soils, unfavorable climate, inadequate infrastructure and logistics.

With regard to research, there were only few experiments involving ICLF systems in Central Brazil until the early 2000s (Daniel et al. 2001); thus guidelines were based on studies carried out in Southeast Brazil. Looking at future research and technology transfer demands, the formal research group 'Sistemas de produção sustentáveis e cadeias produtivas da pecuária de corte (GSP)' (Sustainable production systems and beef cattle value chains) from Embrapa Beef Cattle, carrying out research in the Cerrado biome (Zimmer et al. 2012), has identified the following needs: (1) to evaluate new forage grass options adapted to shading under ICLF; (2) to evaluate forage legume options aiming to interrupt the cycle of parasites and diseases, while improving nitrogen fixation, reducing production costs and improving animal diets, with emphasis on yield; (3) to select tree species to broaden options beyond eucalypts; (4) to develop cultivation strategies to allow tree planting while retaining pastures, without sowing grain crops, when local conditions are unsuitable for planting a grain crop or farmers are unwilling to sow one; (5) to expand experiments with extensive dairy and sheep production; (6) to improve assessments of carbon balance and life-cycle analysis of products from ICLF systems; (7) to improve long-term experiments in strategic locations, in 
order to evaluate carbon dynamics and soil quality changes; (8) to expand technology transfer initiatives and assessment of economic aspects of ICLF systems, especially on commercial farms in different areas; and (9) to establish a strategic zoning for different ICLF systems, considering soils, climate and existing infrastructure.

\section{North Region}

The North region covers the States of Acre, Amapá, Amazonas, Pará, Rondônia, Roraima and Tocantins, and is the largest area, with $3.86 \mathrm{Mkm}^{2}$ (45\% of the national territory). As the region with the lowest population density, it is currently the Brazilian agricultural frontier. An equatorial climate is predominant, and Amazon or Equatorial Rain Forest covers $90 \%$ of the surface, with some fragments of Cerrado. Pastures occupy 26.9 Mha, carrying 43.2 M cattle and 0.6 M sheep (IBGE 2006a; 2011).

Most of the research on silvopastoral systems in Northern Brazil involves isolated and incremental studies to: (1) select forage species tolerant of shading; (2) identify promising native tree species for silvopastoral systems; (3) broaden knowledge on selected native tree species; (4) evaluate introduced tree species like eucalypts (Eucalyptus spp.), teak (Tectona grandis), African mahogany (Khaya ivorensis) and Indian neem (Azadirachta indica); and (5) evaluate certain interactions among system components, especially tree-forage-soil.

As a whole, there is a lack of studies about productive and reproductive performance of animals in these systems, especially long-term, multi-disciplinary studies carried out in mature silvopastoral systems.

Despite advances in the last 15-20 years, silvopastoral and ICLF systems can still be considered developing technologies in Northern Brazil. For this reason, adoption levels are still low and a series of technical and socioeconomic hindrances have been identified (Dias-Filho and Ferreira 2008): (1) the need for relatively high initial investments with tree plantation and cultivation practices; (2) low turnover, with low initial profitability (first 3-4 years); (3) higher intrinsic complexity of integrated systems, demanding more commitment and higher level of knowledge regarding tree species and future market prospects for tree products; and (4) farmers' incomplete perception regarding benefits of silvopastoral systems beyond shading for cattle.

The most common silvopastoral system in Northern Brazil is the scattered trees on pastures model, usually with native trees from natural recovery. This happens because shading is the major motivation for farmers to have trees on pastures, since local high temperatures and humidity cause remarkable thermal stress on cattle, especially crossbreds with higher European content. In this region, potential losses in milk production caused by thermal stress range from 10 to $20 \%$ in cows yielding $15 \mathrm{~L} / \mathrm{d}$ (INMET 2012). In the Cerrado pockets in the Northern region, integrated systems follow the patterns used in Central Brazil.

\section{Northeast Region}

The Brazilian Northeast encompasses the States of Alagoas, Bahia, Ceará, Maranhão, Paraíba, Pernambuco, Piauí, Rio Grande do Norte and Sergipe, with a total area of $1.55 \mathrm{Mkm}^{2}$ or $18 \%$ of Brazil. From that, $0.96 \mathrm{Mkm}^{2}$ are located in the semi-arid zone of the country. Pastures occupy $30.6 \mathrm{Mha}$, of which $52 \%$ is natural grasslands, supporting a total of $29.6 \mathrm{M}$ cattle, $10.1 \mathrm{M}$ sheep and 8.5 M goats (91\% of the national goat herd) (IBGE 2006a; 2011).

The predominant climate is hot semi-arid with annual rainfall ranging from 400 to $650 \mathrm{~mm}$, and irregular precipitation, with dry periods up to 8 months per year. Sometimes the dry season can be even longer; this phenomenon is cyclical and can occur from once in 3 years to once in 10 years. Caatinga is the main vegetation type, composed of a variety of xerophytic plant types including monocots and dicots, and from thorny woody species to succulents (Araújo Filho 2006). Average biomass production in Caatinga is $4 \mathrm{t} \mathrm{DM} / \mathrm{ha} / \mathrm{yr}$, of which only $10 \%$ is considered edible forage. Animal and plant production systems are diversified, with cattle usually kept along with sheep and goats. In cropping areas, subsistence agriculture is carried out, with animals grazing crop residues. In the traditional systems, 'slashing and burning' of native vegetation for establishing new cultivation areas, as well as overgrazing of natural grasslands, has caused negative impacts on the ecosystem, increasing the area undergoing degradation and desertification (Carvalho 2006).

Production systems based on agroforestry have been proposed as an alternative to the traditional model. The goal is to ensure both ecosystem stability and sustainability of agricultural production by means of adapted land use practices in this difficult environment. The agrosilvopastoral system proposed aims to stabilize agriculture, efficiently use native vegetation as forage and rationalize wood extraction in an integrated and diversified way (Araújo Filho et al. 2006). Strategies for reaching these goals start by eliminating fire and complete deforestation. Next, tools for forage budgeting are used to adjust stocking rate and, finally, a systematic pruning management of native trees is proposed to exploit local wood and timber potential. The resulting system is composed of 3 modules: crop, pasture and forest.

Selective thinning of forest occurs instead of complete 
land clearing, with $10-15 \%$ of the area kept mainly with native trees (Araújo Filho et al. 1998a). Subsequently, bush/tree species, mainly Gliricidia sepium and Leucaena leucocephala, are planted to be used as green manure in the rainy season. They are combined with crops like maize, beans, sesame, cotton, castor bean and sorghum. Legume trees are kept low and their canopy, at the end of the rainy season, can be used as hay for animal feeding. From the second year, these legumes can be browsed by sheep and goats at the beginning of the dry season. With forest thinning, available understory forage vegetation increases and can be grazed after crop harvesting at the end of the rainy season. In the dry season the grass component and crop residues on the area can be grazed. The crop component, therefore, contributes to both plant and animal production.

The pasture component is a Caatinga area where $30-40 \%$ of the tree cover is kept, varying according to the floristic composition. The maximum level of utilization of the pasture allowed is $60 \%$. Knowing the floristic composition is essential for setting the management plan, which might estimate stocking rates based on forage availability. This is important to avoid degrading the forage potential of native grasslands. Forest thinning as a management strategy for Caatinga can increase the amount of forage available to grazing animals from 10 to $90 \%$ (Araújo Filho et al. 2002). As a strategy to improve forage production, perennial grass species like Cenchrus ciliaris, Urochloa mosambicensis and Panicum maximum cv. Massai, can be introduced, producing up to an additional $3 \mathrm{t}$ of forage per ha. Stocking rates have varied from 0.5 to 3 ha per adult sheep or goat. Areas combining thinning with improved grasses show the highest carrying capacities.

The forest component is the original Caatinga vegetation itself. Some species with timber potential are cut in 7year average cycles and can be used either for timber or forage (Carvalho et al. 2004). This forest area can be used for grazing during the dry season (Araújo Filho et al. 1998b). The basis of agrosilvopastoral systems for the Caatinga is manipulating the woody component to allow development of the understory. This procedure is still done by hand, for both the system implementation and maintenance, so one of the major limitations for such systems is rural labor scarcity (Campanha et al. 2010). As a possible solution, there is a current trend of developing appropriate machinery for mechanizing this activity, specific to Caatinga conditions, including its topography. These machines must be able to cut trees and regrowth bushes as well as grinding their branches and stems, reducing demand for labor.

Seeding and crop maintenance are also carried out manually. The fact that this model precludes the use of herbicides and chemical pesticides increases the need for labor. Mechanization of activities and the use of biological pest control and plant-based products to restrain growth without eliminating native grasses, can help solve the labor problem.

In animal production the use of plant-based products is recommended for control of the main diseases, especially worms. In the integrated system, this problem is more acute in goats than sheep (Campanha et al. 2010), making sheep husbandry more viable than dairy goats. The latter represent a very interesting option to ensure a quick return on investment. In the semi-arid region, this activity is currently included in several governmental programs; thus, it should not be left aside as an option for the system. To succeed, farmers must have some previous experience with dairy animal management, in order to avoid sanitary problems, which mostly affect the system's economic viability.

Adjusting stocking rates through grazing management is also a challenge (Campanha et al. 2010). It is important that, when working with the native grass components, local forage resources are known, in order to make stocking rate adjustments based on both quality and quantity of biomass. Basing decisions only on biomass quantity can lead to degradation through overgrazing of highly palatable forage species, leaving behind the less palatable ones. Establishing a workable grazing management policy, with welldefined grazing and resting periods, is crucial for this kind of system.

There is also a need to make better use of the timber potential of some native Caatinga species that are part of the system's forest component.

Since these systems present some differentiated characteristics like sustainable use of natural resources, family labor and traditional goods, costs are higher and yields are lower, making it difficult to compete in the regular market with conventional products from the area. Therefore, it is necessary to better explore specific market niches like fair trade and organic product markets, adding value to goods coming from such production systems. Another important aspect is the need for an environmental services compensation policy. At least 3 services from the system can be identified: plant biodiversity; carbon sequestration; and organic matter deposition in the soil (Aguiar 2011).

In short, agrosilvopastoral systems for the Brazilian semi-arid areas are a group of aggregated technologies aiming at sustainable plant and animal agriculture. These technologies can be grouped according to the 3 components:

- Crop component: no burning, improved maize and sorghum varieties adapted to the area, crops for biodiesel production, environmental service as biodiversity preservation and organic matter deposition, no-tillage seeding.

- Cattle component: sustainable management of 
Caatinga vegetation through management of the woody component for animal grazing, use of locally produced low-cost supplements (e.g. sorghum silage, crop residues and protein-forage reserves).

- Forest component: Mimosa caesalpiniifolia ('sabiá') management for wood and forage production.

Agrosilvopastoral systems in the Brazilian semi-arid areas, despite their technological challenges, have been adopted mainly by rural communities, whose production model is based on agroecological principles and land redistribution projects. Such communities adhere to the basic principles of the model, like no use of fire, selective cutting of tree species and preservation of gallery forests. Additionally, these communities have inserted some new elements into the system, expanding product diversity through growing different traditional crops like cassava, castor bean and melons and harvesting wild honey.

These systems are evolving; the basic principles are well defined. Therefore it is necessary to solve minor technical hindrances and focus on broader aspects, involving policies and markets, so that the full potential of agrosilvopastoral systems in the semi-arid areas can generate better living conditions for the significant population in this part of Brazil.

\section{South Region}

The Brazilian Southern region encompasses the States of Paraná, Rio Grande do Sul and Santa Catarina, and covers $0.58 \mathrm{Mkm}^{2}$ (7\% of the national territory), being the second most developed region in the country and the one with the largest Human Development Index (HDI). It keeps about $13 \%$ of the Brazilian cattle herd and $28 \%$ of the sheep flock, with pastures covering around 16 Mha (IBGE 2006a; 2011). In Rio Grande do Sul and Santa Catarina, natural grasslands constitute more than $80 \%$ of the total pasture area. Climate varies from tropical to humid subtropical, with a predominance of the latter. Vegetation is characterized by tropical forests at the coast and subtropical forests in the inland. In the southern part, the biome is called Campos Sulinos (Southern Plains, a grass-bush steppe). Cattle in this region enjoy a good level of herd management; however, production is still less than its technical potential because of limiting factors like seasonal feed deficiency and pasture degradation.

In Southern Brazil, Paraná State has the longest record of silvopastoral systems, especially in beef cattle operations. The main driver for their adoption is the beneficial presence of trees on pastures, serving as shelter for cattle and reducing frost effects on the forage in colder months (Ribaski et al. 2012).
Other initiatives developed in the region, particularly in Rio Grande do Sul, emphasize silvopastoral systems as an important strategy for sustainable rural development. At the Campos Sulinos, forage production of tropical and subtropical grasses is markedly seasonal. This kind of vegetation has a major influence on the socio-economic life of farmers, due to its importance as a forage source for their cattle and sheep herds plus other livestock species (Coelho 1999). However, natural fragility of soils, together with their low suitability for crops, as well as traditional land use for extensive cattle ranching, has accelerated erosion, leading to a gradual increase of areas with scattered vegetation and large bare areas with sandy soils. These environmental losses have had negative impacts on socioeconomic conditions, leading to a decline in farmers' livelihoods. Sustainable development in the area has been the subject of several studies and there is consensus on the need to diversify the local production matrix, in order to improve income of the productive sector. The use of silvopastoral systems has been seen as an important strategy for sustainable land use, and also as a new source of added value for farmers through wood production (Ribaski et al. 2012).

\section{Conclusion}

Despite many benefits from ICLF systems for cattle production and availability of appropriate technologies, there are still limiting factors for their broader adoption in Brazil, especially related to research, technology transfer, capacity building and credit availability. However, in the last 5 years, the Brazilian Government has strongly invested in these aspects, aiming to overcome the above limitations. Implementation of research on those issues raised as priorities will improve the likelihood of increased adoption of these production systems.

\section{References}

Aguair KR. 2011. Valoração e pagamento dos serviços ambientais: Alternativa de rentabilidade extra para um sistema agrossilvipastoril do bioma Caatinga. M.Sc. Thesis. Universidade Federal do Ceará, Fortaleza, CE, Brazil.

Almeida RG; Barbosa RA; Zimmer AH; Kichel AN. 2012a. Forrageiras em sistemas de produção de bovinos em integração. In: Bungenstab DJ, ed. Sistemas de integração lavoura-pecuária-floresta: A produção sustentável. 2nd Edn. Empresa Brasileira de Pesquisa Agropecuária (Embrapa), Brasília, DF, Brazil. p. 87-94.

Almeida RG; Zimmer AH; Kichel AN; Macedo MCM; Costa JAA. 2012b. Estratégias de recuperação de pastagens por intermédio de sistemas integrados de produção de carne 
bovina. Proceedings of the 22nd Congresso Brasileiro de Zootecnia - Zootec 2012, Universidade Federal de Mato Grosso, Cuiabá, MT, Brazil.

Andrade CMS; Garcia R; Couto L; Pereira OG. 2001. Fatores limitantes ao crescimento do capim-tanzânia em um sistema agrossilvipastoril com eucalipto, na região dos cerrados de Minas Gerais. Revista Brasileira de Zootecnia 30: $1178-1185$.

Araújo Filho JA. 2006. O bioma Caatinga. In: Falcão Sobrinho J; Falcão CLC, eds. Semi-árido: Diversidade, fragilidade e potencialidades. Sobral Gráfica, Sobral, CE, Brazil. p. 49-70.

Araújo Filho JA; Barbosa TML; Carvalho FC; Cavalcante ACR. 1998a. Sistema de produção agrossilvipastoril para o semiárido nordestino. Proceedings of the 2nd Congresso Brasileiro de Sistemas Agroflorestais. Empresa Brasileira de Pesquisa Agropecuária (EMBRAPA)-CPATU, Belém, PA, Brazil. p. 187-188.

Araújo Filho JA; Leite ER; Silva NL. 1998b. Contribution of woody species to the diet composition of goat and sheep in Caatinga vegetation. Pasturas Tropicales 20(2):41-45.

Araújo Filho JA; Carvalho FC; Garcia R; Sousa RA. 2002. Efeito da manipulação da vegetação lenhosa sobre a produção e compartimentalização da fitomassa pastável de uma caatinga sucessional. Revista Brasileira de Zootecnia 31:11-19.

Araújo Filho JA; Holanda Jr EV; Silva NL; Sousa FB; Franca FM. 2006. Sistema agrossilvipastoril - Embrapa Caprinos. In: Lima GFC; Holanda Jr EV; Maciel FC, eds. Criação familiar de caprinos e ovinos no Rio Grande do Norte: Orientações para viabilizar o negócio rural. EMATER-RN, Natal, RN, Brazil. p. 105-131.

Balbino LC; Barcellos AO; Stone LF. 2011a. Marco referencial: integração lavoura-pecuária-floresta. Empresa Brasileira de Pesquisa Agropecuária (Embrapa), Brasília, DF, Brazil.

Balbino LC; Martinez GB; Galerani PR. 2011b. Ações de transferência de tecnologia para integração lavoura-pecuáriafloresta 2007-2010. Embrapa Cerrados, Planaltina, DF, Brazil.

Bernardino FS; Tonucci RG; Garcia R; Neves JCL; Rocha GC. 2011. Produção de forragem e desempenho de novilhos de corte em um sistema silvipastoril: Efeito de doses de nitrogênio e oferta de forragem. Revista Brasileira de Zootecnia 40:1412-1419.

Campanha MM; Pereira VG; Bomfim MAD. 2010. Sistema agrossilvipastoril caprinos e ovinos: Reunião técnica. Documentos No. 97. Embrapa Caprinos e Ovinos, Sobral, CE, Brazil.

Carvalho FC. 2006. Sustentabilidade de sistemas agroflorestais pecuários em ambiente semi-árido. In: Falcão Sobrinho J; Falcão CLC, eds. Semi-árido: Diversidade, fragilidade e potencialidades. Sobral Gráfica, Sobral, CE, Brazil. p. 71-109.

Carvalho FC; Garcia R; Araújo Filho JA; Couto L; Neves JCL; Rogério MCP. 2004. Manejo in situ do Sabiá (Mimosa caesalpiniifolia Benth.) para a produção simultânea de madeira e forragem, em um sistema silvopastoril. Revista Brasileira de Zootecnia 1:121-129.

Carvalho JLN; Raucci GS; Cerri CEP; Bernoux M; Feigl BJ;
Wruck FJ; Cerri CC. 2010. Impact of pasture, agriculture and crop-livestock systems on soil C stocks in Brazil. Soil and Tillage Research 110:175-186.

Carvalho MM; Xavier DF; Alvim MJ. 2001. Uso de leguminosas arbóreas na recuperação e sustentabilidade de pastagens cultivadas. In: Carvalho MM; Alvim MJ; CarneiroJC, eds. Sistemas agroflorestais pecuários: Opções de sustentabilidade para áreas tropicais e subtropicais. Embrapa Gado de Leite and FAO, Brasília, DF, Brazil. p. 189-204.

Coelho RW. 1999. Manejo de pastagens melhoradas de inverno. Circular Técnica No. 17. Embrapa Clima Temperado, Pelotas, RS, Brazil.

Costa JAA; Cardoso EE; Reis FA; Oliveira AR; Silva WC. 2011. Perspectivas da pesquisa em ovinocultura de corte no Centro-Oeste. Documentos No. 184. Embrapa Gado de Corte, Campo Grande, MS, Brazil.

Daniel O; Passos CAM; Couto L. 2001. Sistemas agroflorestais (silvipastoris e agrossilvipastoris) na Região Centro-Oeste do Brasil: Potencialidades, estado atual da pesquisa e da adoção de tecnologia. In: Carvalho MM; Alvim MJ; Carneiro JC, eds. Sistemas agroflorestais pecuários: Opções de sustentabilidade para áreas tropicais e subtropicais. Embrapa Gado de Leite and FAO, Brasília, DF, Brazil. p. $153-164$.

Dias-Filho MB; Ferreira JN. 2008. Barreiras à adoção de sistemas silvipastoris no Brasil. Documentos No. 347. Embrapa Amazônia Oriental, Belém, PA, Brazil.

Euclides VPB; Valle CB; Macedo MCM; Almeida RG; Montagner DB; Barbosa RA. 2010. Brazilian scientific progress in pasture research during the first decade of XXI century. Revista Brasileira de Zootecnia 39:151-168.

Ferraz JBS; Felício PE. 2010. Production systems - an example from Brazil. Meat Science 84:238-243.

Garcia R; Couto L. 1997. Sistemas silvipastoris: Tecnologia emergente de sustentabilidade. Proceedings of the 1 st Simpósio Internacional sobre Produção Animal em Pastejo. Universidade Federal de Viçosa, Viçosa, MG, Brazil. p. $447-471$.

IBGE (Instituto Brasileiro de Geografia e Estatística). 2006a. Área dos estabelecimentos agropecuários por utilização das terras (Tabela 854).

(Retrieved 20 February 2013 from www.sidra.ibge.gov.br/bda/tab-ela/listabl.asp? $\mathrm{z}=\mathrm{t} \& \mathrm{c}=854)$.

IBGE (Instituto Brasileiro de Geografia e Estatística). 2006b. Área dos estabelecimentos agropecuários por utilização das terras (Tabela 1011). (Retrieved 20 February 2013 from www.sidra.ibge.gov.br/bda/tab-ela/listabl.asp?z=t\&c=1011).

IBGE (Instituto Brasileiro de Geografia e Estatística). 2011. Pesquisa Pecuária Municipal: Efetivo dos rebanhos por tipo de rebanho (Tabela 73).

(Retrieved 20 February 2013 from

www.sidra.ibge.gov.br/bda/tab-ela/listabl.asp? $\mathrm{z}=\mathrm{t \& c}=73$ ).

INMET (Instituto Nacional de Meteorologia). 2012. Potencialidade de perda na produção leiteira.

(Retrieved 10 May 2012 from

www.inmet.gov.br/agrometeorologia/IndProdLeite15.php). 
Macedo MCM. 2005. Pastagens no ecossistema Cerrados: Evolução das pesquisas para o desenvolvimento sustentável. Proceedings of the 42nd Reunião Anual da Sociedade Brasileira de Zootecnia. CD-ROM. SBZ (Sociedade Brasileira de Zootecnia), Goiânia, GO, Brazil. p. 56-84.

Macedo MCM. 2010. Integração lavoura-pecuária-floresta: Alternativa de agricultura conservacionista para os diferentes biomas brasileiros. Proceedings of the 18th Reunião Brasileira de Manejo e Conservação do Solo e da Água. Embrapa Meio-Norte, Teresina, PI, Brazil.

Ofugi C; Magalhães LL; Melido RCN; Silveira VP. 2008. Integração lavoura-pecuária-floresta (ILPF), sistemas agroflorestais (SAF's). In: Trecenti R; Carvalho de Oliveira M; Hass G, eds. Integração lavoura-pecuária-silvicultura. Boletim técnico. Ministério da Agricultura, Pecuária e Abastecimento (MAPA), Brasília, DF, Brazil. p. 20-25.

Paciullo DSC; Castro CRT; Gomide CAM; Fernandes PB; Rocha WSD; Müller MD; Rossiello ROP. 2010. Soil bulk density and biomass partitioning of Brachiaria decumbens in a silvopastoral system. Scientia Agricola 67:401-407.

Paciullo DSC; Castro CRT; Gomide CAM; Maurício RM; Piresa MFA; Müller MD; Xavier DF. 2011. Performance of dairy heifers in a silvopastoral system. Livestock Science 141:166-172.

Porfírio-da-Silva V; Baggio AJ. 2003. Como estabelecer com sucesso uma Unidade de Referência Tecnológica em sistema silvipastoril. Documentos No. 83. Embrapa Florestas, Colombo, PR, Brazil.
Ribaski J; Radomski MI; Ribaski SAG. 2012. Potencialidade dos sistemas silvipastoris para a produção animal sustentável no Brasil. Proceedings of the 1st Seminario Internacional de Silvopastoreo. Universidad Nacional de Colombia, Medellín, Colombia. p. 1-31.

Sano EE; Barcellos AO; Bezerra HS. 1999. Área e distribuição espacial de pastagens cultivadas no cerrado brasileiro. Boletim de Pesquisa No. 3. Embrapa Cerrados, Planaltina, DF, Brazil.

Serrão EAS; Uhl C; Nepstad DC. 1993. Deforestation for pasture in the humid tropics: Is it economically and environmentally sound in the long term? Proceedings of the XVII International Grassland Congress, Rockhampton, Australia and Palmerston North, New Zealand. p. 2215-2221.

Teixeira LB; Simão Neto M; Teixeira Neto JF. 2000. Pesquisas com pastagens cultivadas na Amazônia. In: Costa NA; Carvalho LODM; Teixeira LB; Simão Neto M, eds. Pastagens cultivadas na Amazônia. Embrapa Amazônia Oriental, Belém, PA, Brazil. p. 17-35.

Zimmer AH; Almeida RG; Bungenstab DJ; Kichel AN. 2012. Integração lavoura-pecuária-floresta no Brasil: Histórico e perspectivas para o desenvolvimento sustentável. Proceedings of the 7th Congresso Latinoamericano de Sistemas Agroflorestais para a Produção Pecuária Sustentável. Universidade Federal do Pará, Belém, PA, Brazil. p. 666-670.

Zimmer AH; Euclides VPB. 2000. Importância das pastagens para o futuro da pecuária de corte no Brasil. Proceedings of the 1st Simpósio de Forragicultura e Pastagens. Universidade Federal de Lavras, Lavras, MG, Brazil. p. 1-49. 
Almeida RG de; Andrade CMS de; Paciullo DSC; Fernandes PCC; Cavalcante ACR; Barbosa RA; Valle CB do. 2013. Brazilian agroforestry systems for cattle and sheep. Tropical Grasslands - Forrajes Tropicales 1:175-183.

DOI: $\underline{10.17138 / \mathrm{TGFT}(1) 175-183}$

This paper was presented at the $22^{\text {nd }}$ International Grassland Congress, Sydney, Australia, 15-19 September 2013. Its publication in Tropical Grasslands - Forrajes Tropicales is the result of a co-publication agreement with the IGC Continuing Committee. Except for adjustments to the journal's style and format, the text is essentially the same as that published in: Michalk LD; Millar GD; Badgery WB; Broadfoot KM, eds. 2013. Revitalising Grasslands to Sustain our Communities. Proceedings of the $22^{\text {nd }}$ International Grassland Congress, Sydney, Australia, 2013. New South Wales Department of Primary Industries, Orange, NSW, Australia. p. 986-992. 